\title{
Effect of Costus igneus: The insulin plant, on pre- diabetes and diabetes in neonatal streptozotocin rats
}

\author{
Murthy EGK Talasila1* , Hemalatha Bavirisetti ${ }^{1}$, Jithendra Chimakurthy², Mayuren Candasamy ${ }^{3}$
}

'Department of Pharmaceutics, Bapatla College of Pharmacy, Bapatla, Andhra Pradesh, India, 2Department of Pharmacology, Bapatla College of Pharmacy, Bapatla, Andhra Pradesh, India, ${ }^{3}$ Department of Life Sciences, International Medical University, Kualalumpur, Malaysia

\begin{abstract}
Introduction: Pre-diabetes is a condition that persists for a considerable duration before progressing into type 2 diabetes mellitus (T2DM). Development of resistance to insulin is the underlying cause of pre-diabetes, preventive measures such as diagnosis, treatment and exercise will preclude its development into T2DM. The present study aims at studying the effect of pre-treatment and post-treatment with isolated fraction of Costus igneus on pre-diabetes and diabetes in neonatal streptozotocin (STZ) induced T2DM.

Methods: Neonatal rats were treated with STZ and differentiated for pre-treatment and post-treatment. Rats of pre-treated group were treated with isolated fraction of Costus igneus (CIF) from $4^{\text {th }}$ week after STZ administration and after $12^{\text {th }}$ week in non-treated rats of post-treatment group. The antihyperglycemic was studied on $7^{\text {th }}$ and $12^{\text {th }}$ week after STZ treatment using oral glucose tolerance test and the hypoglycemic effect was studied on day $1,7,14$ and 21 of treatment after $12^{\text {th }}$ week of STZ treatment in both pre and post treated groups.
\end{abstract}

Results: Oral glucose tolerance test on $7^{\text {th }}$ and $12^{\text {th }}$ week had shown a protective effect against increase in blood glucose levels in pre-treated groups whereas, no such significant decrease was observed in non-treated groups. In the effect on hypoglycemia, a reduction in blood glucose levels was observed on treatment with CIF in both pre and post treated rats on $14^{\text {th }}$ and $21^{\text {st }}$ day.

Conclusions: Treatment with CIF in pre-diabetic stage could reduce the chances of progression into T2DM and is also beneficial in diabetic rats, which could be due to increase in the peripheral utilization of glucose and the insulin mimetic effect of Costus igneus.

Keywords: Prediabetes; Type 2 Diabetes mellitus; Costus igneus; streptozotocin; neonatal

\section{INTRODUCTION}

Development of impaired glucose tolerance is an indication of pre-diabetes (1), which later cause

\footnotetext{
*Corresponding Author: Dr. T.E. Gopala Krishna Murthy, Department of Pharmaceutics, Bapatla college of Pharmacy, Bapatla, Guntur (Dt), AP, India - 552101, Phone: 08643224144 , Fax: 08643 221407. E-mail: bcp.principal@gmail.com.
}

Submitted July 142014 / Accepted September 152014 a gradual increase in resistance to insulin (2) thus causing the risk of type 2 diabetes mellitus (T2DM) (3) if left unattended, making it the initial avoidable indications of T2DM. The incidence of pre-diabetes is increasing at an alarming rate in the developing countries (4) and as $70 \%$ of these will turn into T2DM (5), identification and abolition of pre-diabetes preclude the occurrence of this otherwise impeccable disorder. The fact that 
obesity and physical inactivity are the most potential causes leading to insulin resistance (6), the precursor to pre-diabetes, can be explained by the role of adipose tissue in the synthesis of various mediators such as Non Esterified Fatty Acids (NEFA's) and adipocytokines such as leptin, TNF-A, resistin andadiponectin (7), which are involved in the pathogenesis of insulin resistance and $\beta$-cell dysfunction (8), the early steps involved in the course of development of whole body insulin resistance in T2DM (9).

Drugs of herbal origin served a major role in the treatment of many ailments since centuries and still continue to be the mainstay in their treatment. Unfortunately, despite extensive research, no alternative drug therapy or herbal medicine has accrued adequate importance in the prevention of progression or treatment of T2DM (10), the most common disorder that affects majority of the population all over the world and considered to be one of the 10 leading causes of morbidity and mortality (11). Though number of plants and phytoconstituents with insulin secretagogue activity were identified (12), they are of minimal use in conditions of hyperinsulinemia, the widely experienced characteristic of T2DM and primary cause of insulin resistance. Provided, very few plants such as Agrimony eupatoria, Helicteres isora and Ipomea batata, etc (13-15), have been mentioned to have an additional insulinomimetic activity along with their insulin secretory effects. Hence search for a potent insulinomimetic with considerable effect on insulin resistance is on, which could be a therapeutic breakthrough in the prevention and treatment of T2DM.

Costus igneus or insulin plant is being used in the traditional folk medicine of various tribes in south East Asia, especially in southern parts of India for the treatment of symptoms such as unexplained weight loss or gain, excessive thirst, hunger, insomnia, weakness or fatigue (16) together which can be characterized as the indicators of pre-diabetes and diabetes. Studies of various researches have reported the therapeutic efficacy of Costus igneus against T2DM (17). Hence the goal of our present study was to report the effect of isolated fractions of various extracts of Costus igneus in neonatal streptozotocin (n5-STZ) model of T2DM in rats (18). The effect on pre-diabetes was studied using oral glucose tolerance test in rats during and after induction of T2DM in the presence and absence of drug treatment. The effect on diabetes was studied after administration of drugs to rats which receive treatment before and after induction of diabetes.

\section{METHODS}

\section{Animals and induction of T2DM}

Adult wistar albino rats of either sex $(350-400 \mathrm{~g})$ were procured from the animal house of Bapatla College of pharmacy (1032/ac/07/CPCSEA), Bapatla, India and were housed for breeding, at a constant temperature $\left(22 \pm 1^{\circ} \mathrm{C}\right)$, relative humidity (40-50\%) and $12-12 \mathrm{~h}$ light/dark cycles were maintained. STZ $90 \mathrm{mg} / \mathrm{kg}$ (freshly prepared acetate buffer $0.1 \mathrm{M}, \mathrm{pH} 4.5)$ was administered intraperitoneally to the neonatal rats (weighing 10-12 g) on day 5, postnatally (n5-STZ) (19) Buffer was administered accordingly to the neonatal rats which serve as control. These rats were separated from their mothers after 4 weeks and provided with standard pellet feed (Rayan's Biotech, Hyderabad) and water ad libitum. Animals were acclimatized to laboratory conditions one week prior to initiation of experiments. The experimental protocol was approved by Institutional animal ethics committee (IAEC/ IV-22/BCOP/2012). The handling and care of animals was performed in accordance with CPCSEA guidelines for the use and care of experimental animals.

\section{Plant material}

Fresh leaves of the plant Costus igneus were collected from ABS botanical gardens, karripatti, (Salem District of Tamilnadu) India. The leaves were identified and authenticated by the botanist Dr. A. Balasubramanian, Executive Director, ABS Botanical Conservation, Research and Training Centre, Salem, Tamilnadu. The voucher specimen AUT/BCP/025 was deposited in the department. The leaves were shade dried and powdered finely for extraction and isolation of various compounds. 


\section{Preparation of extract and isolation of the compounds}

Costus igneus leaf powder (50 gm) was subjected to soxhlet extraction with petroleum ether for $12 \mathrm{hrs}$ for defatting. The solvent was then evaporated and extract was dried using rotavac at a controlled temperature of $40-50^{\circ} \mathrm{C}$. The resulting marc was subjected to soxhlet extraction with $300 \mathrm{ml}$ of methanol for 24 hrs. The solvent was removed using rotavac apparatus and the resulting extract was subjected to extraction with various solvents as previously described by Lui (20). The chloroform extract, which was found to be effective when studied for its effect on fasting blood glucose, was subjected to fractionation by preparative TLC, using $20 \times 20 \mathrm{~cm}$ glass plates $(0.5 \mathrm{~mm})$ coated with silica gel $\mathrm{G}$. The fractions were eluted with the chloroform and were screened for blood glucose lowering effect in normal rats and the biologically active Costus igneus fraction (CIF) was selected for the study.

\section{Acute toxicity studies}

Acute toxicity studies of the isolated fraction CIF was administered to male albino mice at doses of 5 , $50,500,2000 \mathrm{mg} / \mathrm{kg}$ body weight orally, to 4 groups of $(n=3)$ overnight fasted mice. They were observed for 24 hours for signs of toxicity and behavioral changes followed by observation for 7 days for morphological changes and mortality.

\section{Grouping of animals}

Rats were divided into two sets, one for pre-treatment and other for post-treatment (i.e. non treated for 12 weeks after STZ administration) each containing five groups $(n=10)$, of which treatment starts from $4^{\text {th }}$ week of STZ administration in pre-treated groups and treatment starts after $12^{\text {th }}$ week of STZ administration in post treated groups. Pre-treated set consists of five groups of which Group I served as control, group II served as negative control, group III and group IV were treated with CIF 20 and $40 \mathrm{mg} / \mathrm{kg}$ and group $\mathrm{V}$ rats were treated with pioglitaozone (PIO) $2.7 \mathrm{mg} / \mathrm{kg}$. CIF and pioglitazone were administered as suspension in $10 \%$ tween 20 (vehicle). Dilutions were made accordingly to administer $0.2 \mathrm{ml} / 100 \mathrm{~g}$ intragastric. Negative control group received vehicle alone. Post treated rats were grouped into 5 groups $(n=10)$, but do not receive any drug treatment till $12^{\text {th }}$ week after STZ administration. All treatments were given intragastric.

\section{Oral glucose tolerance test (OGTT)}

OGTT was performed in pre-treated and post treated groups on $7^{\text {th }}$ and $12^{\text {th }}$ week after STZ treatment. An additional 4 groups of normal rats of equal age were used to study the effects of these treatments on OGTT. The effect of CIF on glucose overloaded hyperglycemia was studied in all the animals. Overnight fasted $(12 \mathrm{~h})$ normal rats were divided into 4 groups $(n=6)$ of which Group I served as control, Group II and Group III were treated with CIF 20 and $40 \mathrm{mg} / \mathrm{kg}$ orally administered, Group IV rats were treated with $2.7 \mathrm{mg} / \mathrm{kg}$ of pioglitazone intragastric. Group I to V of pre-treatedn 5-STZ rats were treated accordingly as discussed above, whereas posttreated $\mathrm{n} 5-\mathrm{STZ}$ rats did not receive any treatment. Zero hour blood glucose levels were determined by tail vein method. After $30 \mathrm{~min}$ of the drug treatment, the animals were fed with glucose $(4 \mathrm{~g} / \mathrm{kg} \mathrm{BW})$ orally and the blood glucose levels were determined after $0.5,1,2$ and 3 hours after glucose administration (21). Blood glucose levels were estimated using a glucometer (Accu-chekActive ${ }^{\mathrm{TM}}$ Test meter).

\section{Hypoglycemic effect in n5-STZ rats after chronic administration}

After performing OGTT on 12 week after STZ administration, rats of both pre and post treated groups were used to study the effect on blood glucose levels. Rats with blood glucose levels $>150 \mathrm{mg} / \mathrm{dL}$ were considered to be diabetic and are included in the study $(n=6)$ (22). All the rats were treated with CIF and pioglitazone for 21 days as described previously. They were used to study the effect of these treatments on hypoglycemia after treatment for 21 days. Fasting blood glucose levels were determined using glucometer (Accu-chekActive ${ }^{\mathrm{TM}}$ Test meter) by tail vein method on day 1, 7, 14 and 21, 30 min after drug administration (23).

\section{Statistical analysis}

All data were expressed as mean \pm SEM. Statistical analysis was performed using one-way analysis of 
variance (ANOVA) followed by Dunnett's test. $\mathrm{p}<0.05$ was considered to be significant.

\section{RESULTS}

\section{Preparative TLC fraction}

The percentage yield of chloroform extract was 6.52 and its TLC profile had shown the presence of two components with $\mathrm{Rf}$ value 0.48 and 0.61 respectively, which were separated using preparative TLC. From $325 \mathrm{mg}$ of chloroform extract, two fractions were obtained namely, CIF-1 (135 mg) and CIF-2 (154 mg). Both the fractions were preliminarily screened for their effect on blood glucose levels in normal rats and CIF-1 was found to have blood glucose lowering effect, hence was selected for the study.

\section{Acute oral toxicity studies}

Acute oral toxicity studies of CIF fraction of chloroform extract did not show any abnormal or toxic symptoms in mice treated with 5, 50, 500, $2000 \mathrm{mg} / \mathrm{kg}$ of the same and the $\mathrm{LD}_{50}$ value is above $2 \mathrm{~g} / \mathrm{kg}$.

\section{Effect on oral glucose tolerance test} In normal rats

Treatment with CIF $20 \mathrm{mg} / \mathrm{kg}$ had shown a significant decrease in the elevated blood glucose levels $(\mathrm{p}<0.01)$ and $(\mathrm{p}<0.001)$ at $2^{\text {nd }}$ and $3^{\text {rd }} \mathrm{h}$ respectively and treatment with CIF $40 \mathrm{mg} / \mathrm{kg}$ had shown a significant decrease $(\mathrm{p}<0.001)$ at $2^{\text {nd }}$ and $3^{\text {rd }} \mathrm{h}$ and the observed effects are similar to that of pioglitazone treatment (Figure 1).

\section{In STZ treated rats}

No significant difference in the basal blood glucose levels were observed in the $7^{\text {th }}$ week of pre-treated and non-treated rats. In OGTT at $7^{\text {th }}$ week, the elevation in blood glucose levels after glucose over loading was more in non-treated rats than that observed in pretreated rats, though not significant. The decrease in the blood glucose levels was significant $(\mathrm{p}<0.01)$ in the $2^{\text {nd }}$ and $3^{\text {rd }}$ h CIF 20 and $40 \mathrm{mg} / \mathrm{kg}$ treated rats (Figure 2). No significant decrease in the blood glucose levels was observed

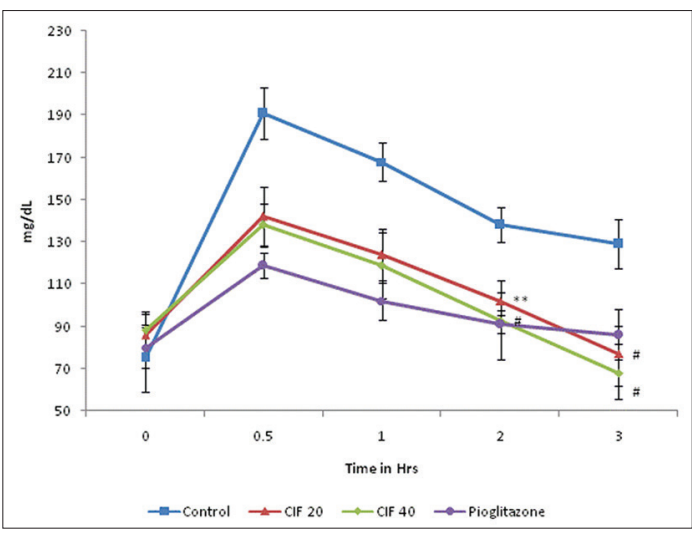

FIGURE 1. Effect of CIF on glucose overloaded hyperglycemia in normal rats ( $n=6)$. Blood glucose levels of $\mathrm{CIF} 20,40$ and pioglitazone treatments were compared with that of control group at respective time intervals $" p<0.01 . " p<0.001$.

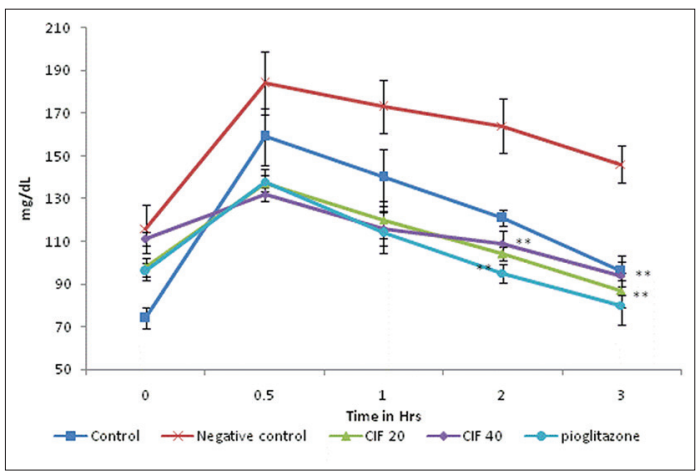

FIGURE 2. Effect on oral glucose tolerance test after $7^{\text {th }}$ week of STZ administration in rats pretreated with CIF $(n=10)$. Blood glucose levels of CIF 20, 40 and pioglitazone treatments were compared with that of negative control group at respective time intervals. $" p<0.05, " p<0.01$.

in non-treated rats. OGTT on $12^{\text {th }}$ week after STZ treatment had shown a significant decrease in the blood glucose levels at $2^{\text {nd }}$ and $3^{\text {rd }} \mathrm{h}$ of treatment with CIF $20 \quad(\mathrm{p}<0.05)$ and $40 \mathrm{mg} / \mathrm{kg}(\mathrm{p}<0.01)$ in pre-treated rats. The increase in blood glucose levels after glucose administration was significant $(\mathrm{p}<0.01)$ (Figure 3) and no significant decrease in the blood glucose levels was observed in nontreated rats.

\section{Effect on hyperglycemia}

Pretreatment with CIF $20 \mathrm{mg} / \mathrm{kg}$ and $40 \mathrm{mg} / \mathrm{kg}$ had shown a significant reduction in blood glucose 
levels on $1^{\text {st }}(\mathrm{p}<0.05), 7^{\text {th }}(\mathrm{p}<0.05), 14^{\text {th }}(\mathrm{p}<0.01)$ and $21^{\text {st }}$ day $(\mathrm{p}<0.001)$ when compared with that of blood glucose levels of negative control group whereas the reduction in blood glucose levels was significant only on $14^{\text {th }}(\mathrm{p}<0.05)$ and $21^{\text {st }}(\mathrm{p}<0.01)$ day, when compared with the blood glucose levels of day 1 (Table 1). Basal blood glucose levels were higher in post treated groups when compared with that of pre-treated rats in day 1 . Post treatment with CIF 20 had shown a significant decrease in the blood glucose levels on $14^{\text {th }}$ and $21^{\text {st }}$ day $(\mathrm{p}<0.05)$ when compared with that of negative control group and $14^{\text {th }}(\mathrm{p}<0.05)$ and $21^{\text {st }}(\mathrm{p}<0.01)$ when compared with the basal blood glucose levels on day 1, and treatment with CIF $40 \mathrm{mg} / \mathrm{kg}$ had shown a significant decrease on $7^{\text {th }}(\mathrm{p}<0.05), 14^{\text {th }}(\mathrm{p}<0.01)$ and $21^{\text {st }}$ day $(\mathrm{p}<0.001)$, when compared with that of negative control group and $7^{\text {th }}(\mathrm{p}<0.05), 14^{\text {th }}(\mathrm{p}<0.05)$

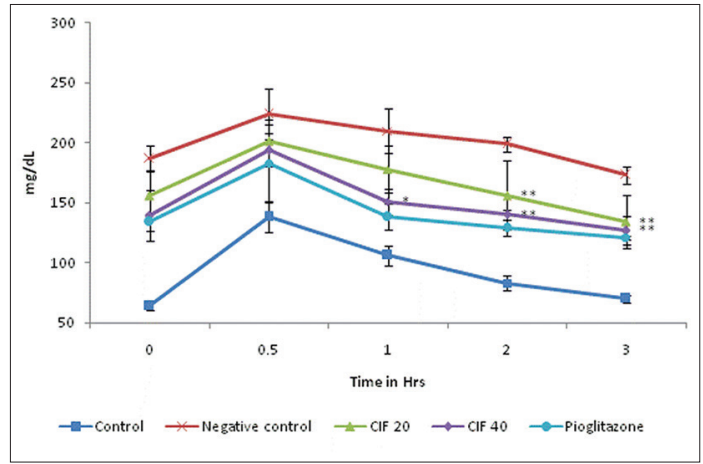

FIGURE 3. Effect on oral glucose tolerance test after $12^{\text {th }}$ week of STZ administration in rats pretreated with $\mathrm{CIF}(n=10)$. Blood glucose levels of CIF 20, 40 and pioglitazone treatments were compared with that of negative control group at respective time intervals. $p<0.05, " p<0.01$. and $21^{\text {st }}$ day $(\mathrm{p}<0.001)$, when compared with the basal blood glucose levels on day 1 (Table 2).

\section{DISCUSSION}

Insulin resistance is the primary cause of development of T2DM, causing significant morbidity and mortality due to various micro and macro vascular changes affecting the quality of life of millions of people all over the world (24). Identification of individuals susceptible to T2DM in their pre-diabetic stage and providing adequate treatment could cut the extent of damage caused. Costus igneus was studied less in terms of its usefulness in the treatment of T2DM despite of its wide usage in many parts of south India. The present study has been designed to explore the possible role of isolated fraction of chloroform extract of Costus igneus on pre-diabetes and diabetes in pre and post treated n5-STZ rats. As n5-STZ rat model produces gradually developing basal hyperglycemia, abnormal glucose tolerance and mild hypoinsulinemia in the initial states of STZ induction up to $7^{\text {th }}$ or $8^{\text {th }}$ week, this could be due to the development of loss of sensitivity of $\beta$-cell towards glucose (25), though a compensatory increase in insulin levels to maintain the blood glucose levels occurs initially, there occurs a failure in such response, due to loss of beta cell sensitivity to glucose, which further inhibit insulin action, thus causing elevated blood glucose levels throughout the day leading to development of insulin resistance.

The effect of CIF on normal glucose overloaded rats in oral glucose tolerance test (OGTT) exhibits its potential in reducing the elevated blood glucose levels. OGTT itself has an ability to detect

TABLE 1. Effect of CIF on blood glucose levels in rats pretreated from $4^{\text {th }}$ week after STZ administration

\begin{tabular}{|c|c|c|c|c|}
\hline \multirow{2}{*}{ Treatment } & \multicolumn{4}{|c|}{ Blood glucose levels $\left(\mathrm{mg} / \mathrm{dL}\right.$ ) at various intervals (days) after $12^{\text {th }}$ week } \\
\hline & 1 & 7 & 14 & 21 \\
\hline Control & $64.3 \pm 4.9^{\mathrm{b \#}}$ & $68 \pm 5.2^{\text {b\# }}$ & $60.5 \pm 7.1^{\mathrm{bH}}$ & $62 \pm 7.1^{\mathrm{bH}}$ \\
\hline Negative control & $197.1 \pm 10.2$ & $188.2 \pm 5.7$ & $193.4 \pm 16.2$ & $175.5 \pm 8.9$ \\
\hline $\mathrm{CIF} 20 \mathrm{mg} / \mathrm{kg}$ & $163.4 \pm 12.1^{1 *}$ & $130.6 \pm 10.4^{\text {ansb* }}$ & $124.3 \pm 11.3^{\mathrm{a} b \mathrm{~b}^{* *}}$ & $103.8 \pm 9.3^{3^{a \star b \#}}$ \\
\hline CIF $40 \mathrm{mg} / \mathrm{kg}$ & $154.4 \pm 10.3^{\mathrm{b} *}$ & $112.1 \pm 7.9^{\text {ansb** }}$ & $103.2 \pm 7.8^{\mathrm{a} \times \mathrm{b} \#}$ & $92.4 \pm 14.2^{2 \star \star b \#}$ \\
\hline $\mathrm{PIO} 2.7 \mathrm{mg} / \mathrm{kg}$ & $158.3 \pm 6.8^{b *}$ & $118.7 \pm 6.8^{\text {ansb** }}$ & $100 \pm 10.2^{\mathrm{a} * \mathrm{b \#}}$ & $82.3 \pm 9.6^{a \star * b \#}$ \\
\hline
\end{tabular}

Data represents mean $\pm S E M$ of blood glucose levels in rats pretreated with CIF from $4^{\text {th }}$ week to 21 days after $12^{\text {th }}$ week of STZ administration. a=represents comparision of blood glucose levels on day 7, 14 and 21 with that of day $1 . b=b l o o d$ glucose levels of all the groups $(n=6)$ were compared with that of negative control group using one way ANOVA followed by Dunnett's test. ${ }^{*} p<0.05$; ${ }^{* *} p<0.01 ; " p<0.001$, ns-non significant 
TABLE 2. Effect of CIF on blood glucose levels in post treated rats during 21 days of treatment from $12^{\text {th }}$ week after STZ administration

\begin{tabular}{|c|c|c|c|c|}
\hline \multirow[t]{2}{*}{ Treatment } & \multicolumn{4}{|c|}{ Blood glucose levels (mg/dL) at various intervals (days) after $12^{\text {th }}$ week } \\
\hline & 1 & 7 & 14 & 21 \\
\hline Control & $71.5 \pm 4.3^{\mathrm{b \#}}$ & $68.2 \pm 6.1^{\mathrm{bH}}$ & $66.1 \pm 4.2^{\mathrm{b \#}}$ & $72 \pm 6.8^{\text {b\# }}$ \\
\hline Negative control & $211 \pm 6.9$ & $204.6 \pm 10.7$ & $207.3 \pm 10.5$ & $216.6 \pm 9.6$ \\
\hline CIF $20 \mathrm{mg} / \mathrm{kg}$ & $216.3 \pm 11.8^{\text {bns }}$ & $184.4 \pm 14.3^{\text {ansbns }}$ & $168.4 \pm 9.3^{3^{a b^{*}}}$ & $154.1 \pm 8.7^{a^{\star \star \star b *}}$ \\
\hline $\mathrm{CIF} 40 \mathrm{mg} / \mathrm{kg}$ & $198.4 \pm 14.3^{\text {bns }}$ & $164.6 \pm 11.3^{\mathrm{a}^{\star \mathrm{b}^{*}}}$ & $141.7 \pm 6.7^{\mathrm{a}^{\star \mathrm{b} \star *}}$ & $102.3 \pm 5.4^{\text {a afb \# }}$ \\
\hline $\mathrm{PIO} 2.7$ mg/kg & $204.2 \pm 12.1^{\text {bns }}$ & $168.3 \pm 6.8^{\mathrm{a} * \mathrm{~b} *}$ & $132.4 \pm 8^{\mathrm{a} * \star \mathrm{b} \#}$ & $98.4 \pm 7.5^{\text {atto\# }}$ \\
\hline
\end{tabular}

Data represents mean \pm SEM of blood glucose levels in rats posttreated with CIF from $12^{\text {th }}$ week to 21 days. a=represents comparision of blood glucose levels on day 7, 14 and 21 with that of day 1. b=blood glucose levels of all the groups $(n=6)$ were compared with that of negative control group using one way ANOVA followed by Dunnett's test. ${ }^{*} p<0.05 ;{ }^{* *} p<0.01 ;{ }^{*} p<0.001$, ns-non significant

the impaired glucose tolerance (26) an indicator of pre-diabetes. As every 1-5\% of individuals with impaired glucose tolerance, develop into T2DM every year and are at a risk of developing heart diseases (27). Neonatal STZ model of diabetes resemble both pre-diabetic and diabetic states of the human (28). In later stages after $7^{\text {th }}$ or $8^{\text {th }}$ week of age there occurs drastic destruction of $\beta$-cells accompanied with peripheral and hepatic resistance of cells against insulin due to prolonged hyperglycemic states (29), which resembles the condition of T2DM in humans. The reduction of blood glucose levels in pre-treated groups after glucose overloading at $7^{\text {th }}$ week indicates the efficacy of CIF on peripheral utilization of glucose levels and could be due to increasing the insulin sensitivity as no such significant decrease in the blood glucose levels were observed in non-treated STZ rats. The effect of OGTT in pre-treated rats is similar to that of observed in normal rats. Whereas, in OGTT after $12 \mathrm{wk}$ of induction pre-treated rats had shown a significant reduction in the blood glucose levels when compared with that of non-treated rats, but was less when compared with that of normal rats. This could be due to the extent of destruction of $\beta$-cellsleading to hypoinsulinemia, that might have occurred in the later stages of STZ induction in both pre-treated and non-treated groups (30). Protection against developing resistance to insulin at peripheral and hepatic tissues and increase in the sensitivity of $\beta$-cells towards glucose in pre-treated groups (31) could be responsible for the observed beneficial effect.

Whereas, in the effect on hypoglycemia, the reduction in blood glucose levels in the pre-treated groups was less than that observed in normal rats when compared to the observed change in the OGTT performed at $7^{\text {th }}$ week, which once again could be due to the destruction of $\beta$-cells in the adult rats. The elevation in the blood glucose levels on $12^{\text {th }}$ week in both pre-treated and non-treated rats could be explained by the destructive phase of pancreatic $\beta$-cells after $8^{\text {th }}$ week of STZ administration.

In post treated rats, the basal blood glucose levels are higher than that observed in rats that receive CIF and pioglitazone from $4^{\text {th }}$ week, this protective effect on pre-treatment could be explained by the fact that though there occurs a disruption of pancreatic $\beta$-cells, there exists insulin sensitivity, which is evident with the low basal blood glucose levels in them. In conclusion, use of CIF as a prophylactic agent in individuals with basal hyperglycemic states could reduce the risk of developing into T2DM and is also of therapeutic value in the treatment of T2DM.

\section{COMPETING INTERESTS}

The authors declare that there is no conflict of interest.

\section{ACKNOWLEDGEMENTS}

The authors would like to thank All India Council for Technical Education (AICTE) for providing financial assistance under Research Promotion Scheme.

\section{REFERENCES}

1. Edelstein SL, Knowler WC, Bain RP, Andres R, Barrett-connor EL, Haffner SM, et al., Predictors of progression from impaired glucose tolerance to NIDDM: An analysis of six prospective studies. Diabetes 1997;46:701-10.http://dx.doi.org/10.2337/diab.46.4.701. 
2. American Diabetes Association. Diagnosis and classification of diabetes mellitus. Diab Care 2006;29:43-8.

3. Meigs JB, Muller DC, Nathan DM, Blake DR, Andres R. The natural history of progression from normal glucose tolerance to type 2 diabetes in the baltimore longitudinal study of aging. Diabetes 2003;52:1475-84.http://dx.doi. org/10.2337/diabetes.52.6.1475.

4. Sushma N, Raju AB. Pre-diabetes: A Review. Int J Biomed Res 2011;2161-70.

5. Horton R. Prediabetes and the potential to prevent diabetes. Lancet 2012;379:2213.http://dx.doi.org/10.1016/S0140-6736(12)60960-X.

6. Scheen AJ. Pathophysiology of type 2 diabetes. Acta Clin Belg 2003;58:335-41. http://dx.doi.org/10.1179/acb.2003.58.6.001.

7. Polyzos SA, Koutouras J, Zavos C. Nonalcoholic fatty liver disease: The pathogenetic roles of insulin resistance and adipocytokines. CurrMol Med 2009:9:299-314.http://dx.doi.org/10.2174/156652409787847191.

8. Li S, Shin HJ, Ding EL, van Dam RM. Adiponectin levels and risk of type 2 diabetes: A systematic review and meta-analysis. JAMA 2009;302:179-88. http://dx.doi.org/10.1001/jama.2009.976.

9. Arner P. The adipocyte in insulin resistance: Key molecules and the impact of the thiazolidinediones. Trends in Endocrinolmetabol 2003;14:137-45. http://dx.doi.org/10.1016/S1043-2760(03)00024-9.

10. Tuomilehto J, Lindstrom J, Eriksson JG, Valle TT, Hamalainen $H$, Parikka PI, et al.,Prevention of Type 2 Diabetes Mellitus by Changes in Lifestyle among Subjects with Impaired Glucose Tolerance. N Engl J Med 2001;344:1343-50.http://dx.doi.org/10.1056/NEJM200105033441801.

11. The top 10 causes of death (World Health Organization) (Internet). 2008 (Updated Jun 2011; cited Dec 2012). Available from: http://who.int/ mediacentre/factsheets/fs310/en.

12. Patel DK, Prasad SK, Kumar R, HemalathaS. An overview on antidiabetic medicinal plants having insulin mimetic property. Asia Pacific JTrop Biomed 2012;2:320-30.http://dx.doi.org/10.1016/S2221-1691(12)60032-X.

13. Gray AM, Flatt PR. Actions of the traditional anti-diabetic plant, Agrimony eupatoria (agrimony): Effects on hyperglycaemia, cellular glucose metabolism and insulin secretion. Br J Nutr 1998;80:109-14.http://dx.doi. org/10.1017/S0007114598001834.

14. Gupta RN, Pareek A, Suthar M, Rathore GS, Basniwal PK, Jain D. Study of glucose uptake activity of Helicteresisora Linn. fruits in L-6 cell lines. Int J Diabetes Dev Ctries. 2009;29:170-73.http://dx.doi. org/10.4103/0973-3930.57349.

15. Ludvik B, WaldhausI W, Prager R, Kautzky-Willer A, Pacini G. Mode of action of ipomoea batatas (Caiapo) in type 2 diabetic patients.Metabol 2003;52:875-80.http://dx.doi.org/10.1016/S0026-0495(03)00073-8.

16. Fatima A, Agarwal P, Singh PP. Herbal option for diabetes: An overview. Asia Pacific J Trop Dis 2012;2:536-44.http://dx.doi.org/10.1016/ S2222-1808(12)60216-3.

17. Vishnu B, Naveen A, Akshay K, Mukesh S, Patil MB. Antidiabetic activity of insulin plant (Costus igneus) leaf extract in diabetic rats. J Phar Res 2010;3:608-12.
18. Szkudelski T. The mechanism of alloxan and streptozotocin action in B cells of the rat pancreas. Physiol res 2001;50:536-46.

19. Kandhare AD, Raygude KS, Kumar VS, Rajmane AR, Visnagri A, Ghule AE et al., Ameliorative effects quercetin against impaired motor nerve function, inflammatory mediators and apoptosis in neonatal streptozotocin-induced diabetic nephropathy in rats. Biomed Aging Pathol 2012;2:173-86.http:// dx.doi.org/10.1016/j.biomag.2012.10.002.

20. Liu WJ. Traditional Herbal Medicine Research Methods: Identification, Analysis, Bioassay, Pharmaceutical and clinical Studies. New Jersey: John Wiley \& Sons Inc; 2011.http://dx.doi.org/10.1002/9780470921340.

21. Edwin JE, Joshi SB, Jain DC. Antidiabetic activity of flower buds of Micheliachampacalinn. Ind J Pharmacol 2008:40:256-60.http://dx.doi. org/10.4103/0253-7613.45151.

22. Andrade Cetto A, MartínezZurita E, Soto Constantino A, Revilla Monsalve $C$, Wiedenfeld $\mathrm{H}$. Chronic hyperglycemic effect of Malmeadepressa root on n5-streptozotocin diabetic rats. J Ethnopharmacol 2008;116:358-62.http:// dx.doi.org/10.1016/j.jep.2007.11.043.

23. Mazumer PM, Farswan M, Parcha V. Effect of isolated active compound (CG-1) of Cassia glauca leaf on blood glucose, lipid profile and atherogenic index in diabetic rats. Ind J Pharmacol 2009;41:182-6.http://dx.doi. org/10.4103/0253-7613.56076.

24. Klein R. Hyperglycemia and microvascular and macrovascular disease in diabetes. Diab Care 1995;18:258-68.http://dx.doi.org/10.2337/ diacare.18.2.258

25. Chandran M, Phillips SA, Ciaraldi T, Henry RR. Adiponectin: More than just another fat cell hormone?.Diab care 2003;26:2442-50.http://dx.doi. org/10.2337/diacare.26.8.2442.

26. Alberti KG, Zimmet PZ. Definition, diagnosis and classification of diabetes mellitus and its complications. Part 1: Diagnosis and classification of diabetes mellitus provisional report of a WHO consultation. Diabet Med 1998;15:539-53.http://dx.doi.org/10.1002/ (SICI)1096-9136(199807)15:7<539::AID-DIA668>3.0.CO;2-S.

27. Ryden L. Guidelines on diabetes, pre-diabetes, and cardiovascular diseases: Executive summary. Eur Heart J 2007;28:88-136.

28. Wang $Y$, Xin X, Zhendong J, Yan H, Xianhui L, Jianzhao W, Manwen J. Anti-diabetic effects of pentamethylquercetin in neonatallystreptozotocin-induced diabetic rats. Eur J Pharmacol 2011;668:347-53.http://dx.doi. org/10.1016/j.ejphar.2011.06.022.

29. Xiaochen H, Juichi S, Yoshiharu O, Ming X, Gustavo B, Yuzo S. Effect of Gosha-jinki-gan (Chinese herbal medicine: Niu-Che-Sen-Qi-Wan) on insulin resistance in streptozotocin-induced diabetic rats. Diab Res clinprac 2003;59:103-11.http://dx.doi.org/10.1016/S0168-8227(02)00203-6.

30. Julie T, Magaly AM, Sidney BP, et al., Neonatal streptozotocin-induced diabetes mellitus: A model of insulin resistance associated with loss of adipose mass. Metabol 2007;56;977-84.http://dx.doi.org/10.1016/j. metabol.2006.05.021.

31. Ahren B. Insulin secretion in neonatallystreptozotocin-injected mice. Diab Res 1989;11:185-90. 